\title{
Growth Surge: How Private Equity Can Scale Up Firms and the Economy
}

by

\author{
Daniel Schwanen, Jeremy Kronick and Farah Omran
}

- Compared to US firms, Canadian companies have lower productivity, and fewer grow into large businesses. At the same time, Canada has experienced a dearth of Initial Public Offerings (IPO) over the last 30 years and, correspondingly, owners of promising Canadian startups and young companies often "exit" by selling their stakes to large foreign companies rather than support their growth in Canada.

- In this context, it is natural to ask what source of capital (and associated expertise) could complement public equity in fostering firm growth in Canada. In this E-Brief, we show that private equity capital (venture capital and private equity) plays such a positive role, nurturing growth, jobs, investment, trade, and productivity in the Canadian economy. In turn, we recommend that governments shift their attention to mechanisms that can help firms grow or gain a more solid footing beyond the initial venture stage.

- This E-Brief examines the role of private equity in scaling up firms and the Canadian economy. It recommends steps that would increase quality investment opportunities and the depth of equity markets in Canada, and at the same time increase the chances that firms will remain in Canada, either through a sale to a Canadian buyer or eventually through an IPO.

Canada has a well-documented productivity gap with the United States. ${ }^{1}$ Among the possible explanations for this gap is Canada's higher share of smaller, lower-productivity firms (Baldwin, Leung and Rispoli 2014). Indeed, a recent Business Development Bank of Canada (BDC) study found productivity among small and medium-sized firms in Canada is particularly poor and that

The authors thank Alexandre Laurin, Glen Hodgson and anonymous reviewers for comments on an earlier draft. The authors retain responsibility for any errors and the views expressed.

1 Canadian firms generate just 73 percent as much Gross Domestic Product (GDP) per hours worked as their US peers, down from over 90 percent in the 1980s. See BDC (2016). 
only 2 percent of mid-sized Canadian businesses, critical for domestic productivity, grew into large businesses with more than 500 employees (BDC 2016).

Incidentally, and more recently, the low rate at which patents initially awarded to Canadian inventors have been successfully commercialized in Canada has also raised concerns (Plant 2017).

Such observations, among others, suggest that firm growth - and the new investment, jobs, and wealth it brings - is not as dynamic as necessary for maximizing Canadians' standards of living. One possible factor holding back firm growth in Canada is the insufficient availability of patient financing, which supports business development beyond the venture stage (Plant 2018).

The most recent World Bank data on stock market capitalization for domestic exchanges puts Canada at 140 percent of GDP in 2017, a number that is normally correlated with robust economic growth. But this high capitalization figure hides the fact that Canada has experienced a dearth of Initial Public Offerings (IPO) over the last 30 years (Carpentier and Suret 2016) and, correspondingly, that owners of promising Canadian startups and young companies often "exit" by selling their stakes to large foreign companies rather than support their growth in Canada.

In this context, it is natural to ask what source of capital (and associated expertise) could complement public equity in fostering firm growth in Canada. In this E-Brief, we show that private equity capital (venture capital and private equity) plays such a positive role, nurturing growth, jobs, investment, trade, and productivity in the Canadian economy. In turn, we recommend that governments, which have been focusing much attention on supporting financing for startups through initiatives such as the former Venture Capital Action Plan and its replacement, the Venture Capital Catalyst Initiative, shift their attention to mechanisms that can help firms grow or gain a more solid footing beyond the initial venture stage.

In that vein, we suggest three policy avenues that would boost the role of capital markets in supporting firm growth more generally. First, the Department of Finance should consider exempting from taxation the capital gains realized on the sale of the shares of certain small businesses, similar to a measure adopted under the US Small Business Jobs Act of 2010. For investors to qualify for capital gains tax exemption, they must have held qualified shares for at least five consecutive years.

Second, governments should remove barriers to institutional investment in Canada's infrastructure. Many of Canada's largest financial institutions, in particular pension funds, invest the bulk of their infrastructureearmarked spending abroad due to lack of opportunities in Canada (Dachis 2017).

Third, the preferential lower tax rate for small business could be better targeted at young and growing businesses, thereby mitigating the disincentives for Canadian firms to grow (Howitt 2015).

\section{Background}

The market value of unlisted shares - i.e., private equity capital, which equals private venture capital plus private equity - has grown from around 55 percent of total equity capital (private stock plus public stock) in 2000 to around 70 percent in 2018 (Figure 1). One reason for this rise in private capital as a share of total equity might be the dearth of public capital. Indeed, IPOs in Canada have been on a steady decline over the last three decades (Carpentier and Suret 2016). Between 1986 and 1995, there were 1,695 IPOs on either the TSX or TSX Venture. This number more than halved, to 805, over the 1996-to-2005 period, while tumbling to 532 from 2006 to 2016, 


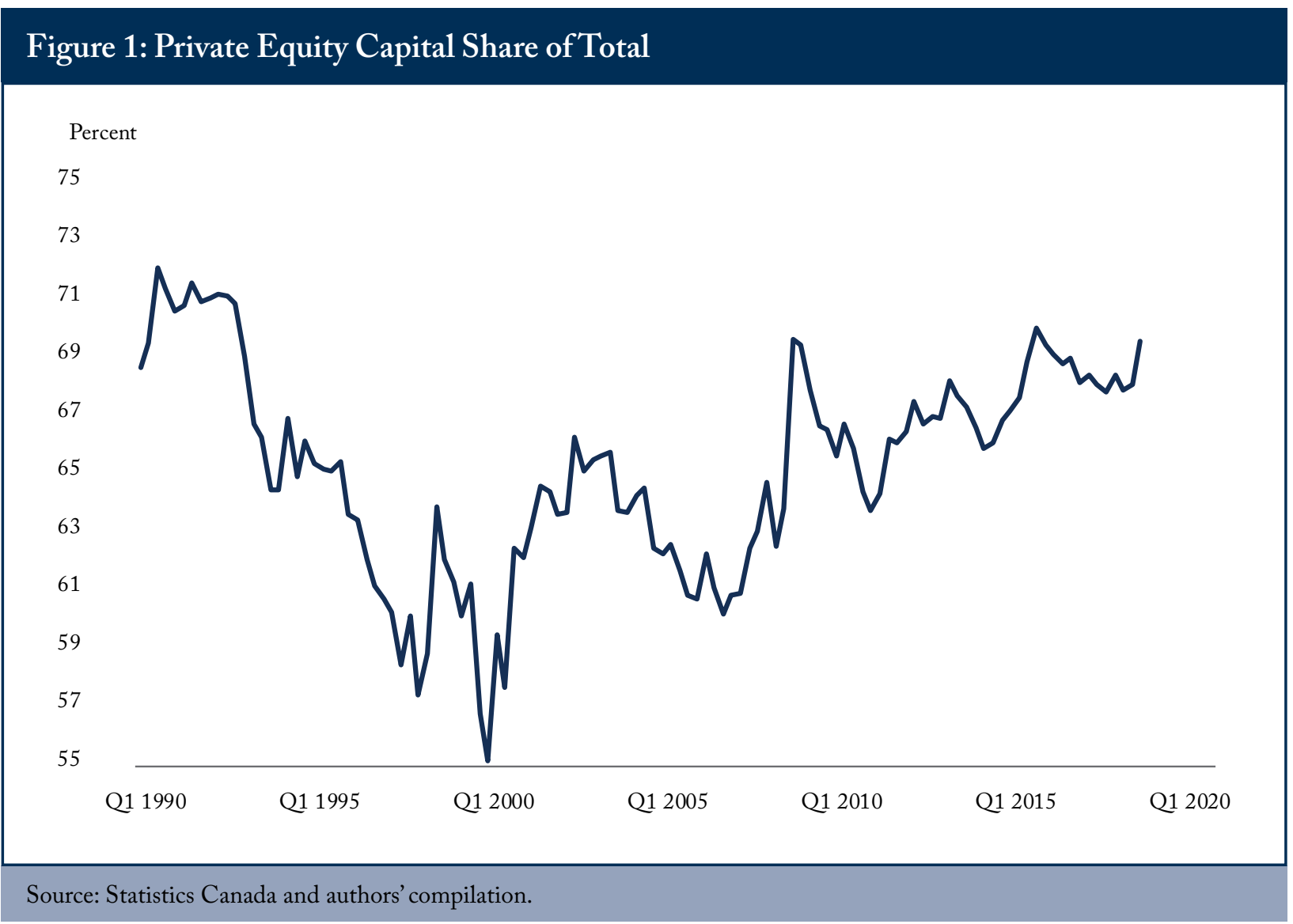

and to just 35 in $2017 .^{2}$ This decline does not discriminate by exchange, though the IPO numbers are worse for the TSX Venture:

- TSX: 304 from 1986-1995, 277 from 1996-2005, 159 from 2006-2016 and 16 in 2017.3

- TSX Venture: 1,391 from 1986-1995, 529 from 1996-2005, 373 from 2006-2016 and 19 in 2017.

This decline in IPOs has accompanied a nearly 15 percent drop in the number of publicly listed companies over the decade-plus from 2007-2018 (TMX Group Ltd. MiG Reports). While the decline in IPOs and in the number of publicly listed companies has naturally coincided with the greater importance of private equity, Figure 1 shows that the current share of private equity capital stock relative to all equity capital is still below its early-1990s level. Furthermore, the market value of both has actually steadily increased although there were market pullbacks during the dot-com bust in 2001, the 2007/08 financial crisis and the 2015 oil price crash (Figure 2).

2 Carpentier and Suret provided us with the 2017 figure, as their published data ended in 2016.

3 Carpentier and Suret (2016) note that: "The annual average number of IPOs reported between 1970 and 1985 by previous studies is lower than that reported since 2006. The asserted IPO decline is grounded in the voluminous, albeit temporary, activity observed at the end of the 1980s." 


\section{Figure 2: Market Value of Private and Public Equity Capital}

\$Billions

7

6

Private Equity Capital

5

4

3

2
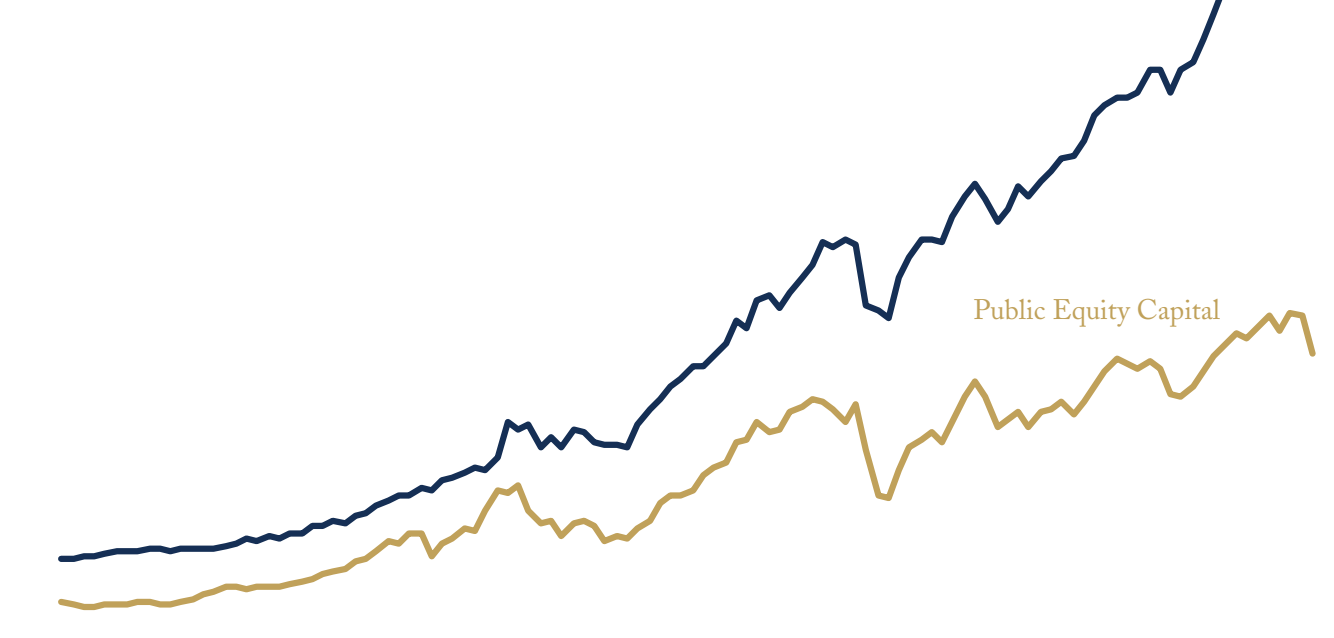

0

Q1 1990

Q1 1995

Q1 2000

Q1 2005

Q1 2010

Q1 2015

Q1 2020

Source: Statistics Canada and authors' compilation.

This rise in private equity capital seems to have complemented the role of public equity. Indeed, we will show that private equity capital plays a positive role in fostering Canadian overall economic activity and growth.

\section{The Role of Private Capital in Fostering Canadian Economic Growth}

In his recent C.D. Howe Institute Commentary, Pierre Lortie points to the positive and complementary role of private equity in the Canadian economy (Lortie 2019). He tests "whether a positive shock to the market value of either private or public equity capital shares leads to a positive response in a series of macroeconomic variables, including real GDP, the employment rate, business fixed capital formation, R\&D (proxied by intellectual property products), and net exports." The study uses a structural vector autoregression, where the private (and public) capital stock growth is ordered as the first variable, making the implicit assumption that this variable is a leading indicator for the economy. This assumption is consistent with Statistics Canada's Composite Leading Indicator Index. ${ }^{4}$

4 Details of the empirical analysis are available in Lortie (2019) or upon request. 


\section{Figure 3: Responses to Increases in Private Equity Investment}
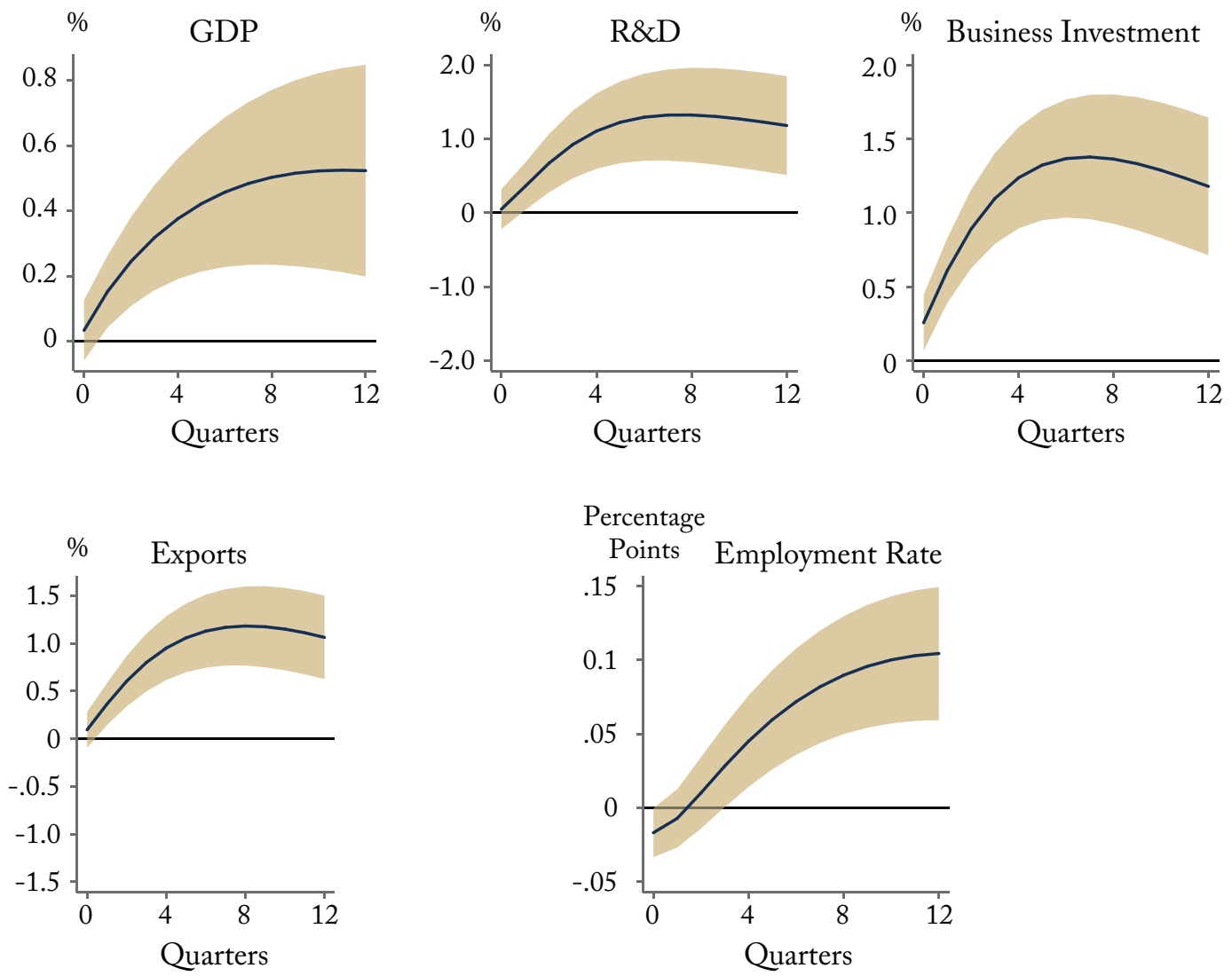

Note: Gold band equals confidence interval.

Source: Lortie (2019) and authors' calculations.

We have built on that study's methodology and updated the results. ${ }^{5}$ In line with Lortie's findings, we conclude that an increase in the stock of private equity capital causes a positive response in the overall economy. The analysis shows that the increase in real GDP is driven by gains in business investment, exports ${ }^{6}$ and, ultimately, productivity and jobs (Figure 3 ). ${ }^{7}$

5 The difference in the figures presented here compared to those in Lortie (2019) is a result of using log levels, instead of growth rates, in order to better capture the long-run effects. Note that the shock to private equity is based on oneunit standard deviation (approximately 0.04 or $4 \%$ ), so readers should not focus too much on the magnitude on the $\mathrm{y}$-axes of the responses of the economic variables.

6 Note that an increase in the stock of private equity leads to a decline in net exports, but this is due to increases in both imports and exports, with the former growing faster than the latter - not an uncommon result when an economy receives a positive demand boost.

7 Similar results hold for public equity capital, emphasizing the complementary nature of private and public capital in fostering economic growth. 


\begin{tabular}{|c|c|c|c|c|c|c|c|c|c|}
\hline \multirow{3}{*}{ Year } & \multicolumn{4}{|c|}{ Top Disclosed Canadian VC Exits } & \multicolumn{5}{|c|}{ Top Disclosed Canadian PE Exits } \\
\hline & \multicolumn{3}{|c|}{$\begin{array}{l}\text { Buyers } \\
\text { (number) }\end{array}$} & \multirow{2}{*}{$\begin{array}{c}\text { Value of } \\
\text { Foreign } \\
\text { Acquisitions } \\
\text { (percent) }\end{array}$} & \multirow{2}{*}{ Year } & \multicolumn{3}{|c|}{$\begin{array}{c}\text { Buyers } \\
\text { (number) }\end{array}$} & \multirow{2}{*}{$\begin{array}{c}\text { Value of } \\
\text { Foreign } \\
\text { Acquisitions } \\
\text { (percent) }\end{array}$} \\
\hline & Foreign & Cdn & $\begin{array}{c}\text { Stock } \\
\text { Exchange }\end{array}$ & & & Foreign & Cdn & $\begin{array}{c}\text { Stock } \\
\text { Exchange }\end{array}$ & \\
\hline 2016 & 5 & - & - & 100 & 2016 & 5 & 3 & 2 & 57 \\
\hline 2017 & 6.5 & 0.5 & 2 & 78 & 2017 & 4.5 & 2.5 & 3 & 71 \\
\hline 2018 & 3 & 1 & - & 47 & 2018 & 6 & - & 4 & 76 \\
\hline Total & 14.5 & 1.5 & 2 & 72 & Total & 15.5 & 5.5 & 9 & \\
\hline
\end{tabular}

\section{Does Private Equity Lead to More Foreign Exits?}

One oft-heard criticism of the rising importance of private equity capital is its association with an increase in foreign acquisitions (Tingle, Pandes and Robinson 2014). However, it is important to distinguish between the components of private equity capital, namely private venture capital, and private equity. Private venture capital (VC) supports small, early-stage companies with a potential for high-growth. Private equity (PE), on the other hand, looks to support companies beyond the venture stage, when they are firmly in the growth and expansion phase.

Using data provided by the Canadian Venture and Private Equity Association (CVCA) on PE deals in Canada over the 2013-2018 period, we can see that over the last three years, the exit stories of Canadian companies in the VC stage are quite different from those in the PE stage (Table 1). For PE exits, there is a near 50-50 split between the number of foreign buyers and the number of either Canadian PE firms or stock exchanges. ${ }^{8}$ On the other hand, approximately 80 percent of buyers in VC exits were foreign. ${ }^{9}$ Furthermore, we note that PE deals over the 2013-2018 period were valued at $\$ 131.3$ billion, while VC deals were a mere $\$ 15$ billion.

8 We focus on the number of exits to different buyers instead of on value for several reasons. First, these are small samples with a wide variation in their values, so one or two deals can significantly skew the value percentages. Second, larger investments naturally represent less risk for foreign investors who are less attuned to the opportunities in the domestic market, whereas the number of smaller investment opportunities, in which domestic buyers invest, can indicate a better, complementary understanding of the growth potential of initially smaller domestic firms.

9 Lortie (2019) also discusses many of the issues with respect to VC exits. 
Table 2: Number (Percentage) of Deals by Scenarios According to Location of Investment and Investor

\begin{tabular}{|c|c|c|c|c|c|c|}
\hline Size of Deal & $\begin{array}{l}\text { Number of } \\
\text { Deals }\end{array}$ & Scenario 1 & Scenario 2 & Scenario 3 & Scenario 4 & Scenario 5 \\
\hline Over $\$ 1$ billion & 85 & $10(12)$ & $5(6)$ & $8(9)$ & $59(69)$ & $3(4)$ \\
\hline$\$ 500$ million to $\$ 1$ billion & 69 & $14(20)$ & $4(6)$ & $7(10)$ & $40(58)$ & $4(6)$ \\
\hline $\begin{array}{l}\text { Sample of deals from } \$ 100 \text { to } \$ 500 \\
\text { million }\end{array}$ & 50 & $23(46)$ & $4(8)$ & $4(8)$ & $15(30)$ & $4(8)$ \\
\hline Sample of deals under $\$ 100$ million & 50 & $33(66)$ & $11(22)$ & $0(0)$ & $4(8)$ & $2(4)$ \\
\hline \multicolumn{7}{|c|}{$\begin{array}{l}\text { Scenario 1: Investment by Canadian PE in the primarily Canadian operations of a Canadian (or sometimes foreign-owned) } \\
\text { business, representing Canadian private investors growing the Canadian firm (or operations) domestically.. }\end{array}$} \\
\hline \multicolumn{7}{|c|}{$\begin{array}{l}\text { Scenario 2: Investment by Canadian or foreign PE in Canadian business expanding or operating internationally, representing } \\
\text { investments geared toward furthering the growth of domestic Canadian firms in international markets. }\end{array}$} \\
\hline \multicolumn{7}{|c|}{$\begin{array}{l}\text { Scenario 3: Foreign PE investors acquiring a Canadian business, or merging it with a foreign business, representing exits } \\
\text { through selling Canadian firms to foreign buyers. }\end{array}$} \\
\hline \multicolumn{7}{|c|}{$\begin{array}{l}\text { Scenario 4: Canadian PE investor investing in (or selling a stake in) international companies not based in Canada, representing } \\
\text { Canadian capital invested in foreign markets.. }\end{array}$} \\
\hline \multicolumn{7}{|c|}{$\begin{array}{l}\text { Scenario 5: Investment by foreign PE in a primarily Canadian business, representing foreign investments in Canadian firms, } \\
\text { while maintaining the core operations, and their benefits to the overall economy, within Canada. }\end{array}$} \\
\hline Source: CVCA database and autho & ' calculations. & & & & & \\
\hline
\end{tabular}

\section{Canadian Private Equity Deals: Key Characteristics}

We are able to draw out some key characteristics of PE deals from the CVCA database that help illustrate their economic impact. These are further parsed and discussed in Lortie (2019, pp. 7-11).

We classified the reported deals under five possible scenarios, described in Table 2, along with the number and percentage of deals (between brackets) falling under each scenario. The main takeaways from this exercise are that:

- Smaller deals were heavily focused on both domestic and international growth of Canadian companies (Scenarios 1 and 2);

- Mid-size deals were more diversified as to their ultimate direction, including proportionately more foreign investment in Canadian companies (Scenarios 3 and 5); and

- Larger deals involved proportionately more Canadian investors looking abroad to buy (Scenario 4).

There is also a correlation between the size of deals and the industry sector. Table 3 shows the industries that are more typically represented in a deal size category than in others. The smaller PE deals are very supportive of the high-growth/high-productivity sectors of Canada's economy, based on sciences and engineering, as well as of traditional industries such as food products and mining. 


\section{Table 3: Industry Concentration of PE Deals According to Their Size}

\begin{tabular}{|c|c|c|c|}
\hline \multirow[b]{2}{*}{ Industry } & \multicolumn{3}{|c|}{ Relative Concentration of Private Equity Deals } \\
\hline & $\begin{array}{c}\text { Large } \\
\text { (over } \$ 1 \text { billion) }\end{array}$ & $\begin{array}{c}\text { Mid-size } \\
(\$ 500 \text { million- } \$ 1 \text { billion })\end{array}$ & $\begin{array}{c}\text { Smaller } \\
\text { (less than } \$ 500 M)\end{array}$ \\
\hline Auto and Transport & $\mathrm{X}$ & $\mathrm{X}$ & \\
\hline Real Estate & $\mathrm{X}$ & $\mathrm{X}$ & \\
\hline Business Products and Services & $\mathrm{X}$ & & \\
\hline Clean Tech & $\mathrm{X}$ & & \\
\hline Financial & $\mathrm{X}$ & & \\
\hline Consumer and Retail & & $\mathrm{X}$ & \\
\hline Oil and Gas and Power & & $\mathrm{X}$ & \\
\hline Agriculture and Food & & & $\mathrm{X}$ \\
\hline $\begin{array}{l}\text { Information \& Communication } \\
\text { Technology }\end{array}$ & & & $\mathrm{X}$ \\
\hline Industrial and Manufacturing & & & $\mathrm{X}$ \\
\hline Life Sciences & & & $\mathrm{X}$ \\
\hline Mining & & & $X$ \\
\hline
\end{tabular}

\section{Policy Recommendations: Deepening Opportunities for Patient Capital in Canada}

The positive role of PE in Canadian economic development could be further enhanced by steps that would increase quality investment opportunities and the depth of equity markets in Canada, and at the same time increase the chances that firms will remain in Canada, either through a sale to a Canadian buyer or eventually through an IPO.

Certainly, public and private players have already launched initiatives in that direction, such as the federal Venture Capital Catalyst Initiative, which in Budget 2017 allocated \$400 million through the BDC to increase the availability of late-stage venture capital. Beyond the venture stage, the Canadian Business Growth Fund, which is supported by Canada's big banks and insurance companies, has a "national mandate to provide long-term patient, minority capital to entrepreneurs pursuing growth and expansion strategies."10

But more is needed to support Canadian business retention and domestic expansion. As in Lortie (2019), we recommend introducing measures similar to those in the US Small Business Jobs Act of 2010, exempting from taxation the capital gains on selling shares of certain small business. These qualified small businesses

10 See https://cbgf.com. 
must be incorporated as a $\mathrm{C}$ corporation (includes essentially all for-profit corporations in the US), have gross assets below $\$ 50$ million before or right after the issuance, must be engaged in a qualified trade or business, and cannot include shares traded on a secondary market. Crucially, investors must have held the shares for at least five consecutive years. ${ }^{11}$ Early returns suggest that investment in SMEs and the number of investors have increased since this policy was put in place (Edwards and Todtenhaupt 2018).

As well, following Dachis (2017), we recommend opening more Canadian infrastructure investments to private investors. This lack of investment opportunities at home is part of the reason Canadian institutional investors seeking to match their liabilities with longer-term assets very actively invest in infrastructure abroad. Investing in domestic infrastructure is good for domestic productivity, and allowing more investment dollars to stay at home would provide a more robust environment for efficient capital allocation.

Finally, as with Robson, Laurin and Wyonch (2018), we recommend reorienting the Small Business Deduction to young and growing firms, in contrast to applying it to all businesses that are small. The idea is to encourage rather than disincent growth (Howitt 2015).

Such a multi-pronged approach would further allow private equity to play its positive role in Canada's economic development, as highlighted in this E-Brief, by enhancing the efficient allocation of capital to firms that have the best prospects for economically beneficial growth.

11 More information on the Act can be found at: https://web.archive.org/web/20161125084303/https://www.sba.gov/ about-sba/sba-initiatives/small-business-jobs-act-2010. 


\section{References}

Baldwin, John R., Danny Leung, and Luke Rispoli. 2014. “Canada-United States Labour Productivity Gap Across Firm Size Classes.” Statistics Canada Research Paper. January.

Business Development Bank of Canada. 2016. “The Scale Up Challenge: How Are Canadian Companies Performing?” September.

Carpentier, Cécile, and Jean-Marc Suret. 2018. “Three Decades of IPO Markets in Canada: Evolution, Risk and Return.” CIRANO Working Paper 2018S-04. March.

Dachis, Benjamin. 2017. New and Improved: How Institutional Investment in Public Infrastructure can Benefit Taxpayers and Consumers. Commentary 473. Toronto: C.D. Howe Institute. March.

Edwards, Alexander, and Maximilian Todtenhaupt. 2018. "Capital Gains Taxation and Funding for StartUps.” ZEW Discussion Paper 18-046. Mannheim: ZEW-Leibniz Centre for European Economic Research. Available at http://ftp.zew.de/pub/zew-docs/dp/dp18046.pdf.

Howitt, Peter. 2015. Mushrooms and Yeast: The Implications of Technological Progress for Canada's Economic Growth. Commnetary 433. Toronto: C.D. Howe Institute. September.

Lortie, Pierre. 2019. Entrepreneurial Finance and Economic Growth: A Canadian Overview. Commentary 536. Toronto: C.D. Howe Institute. February.

Plant, Charles. 2017. Canada's Patent Puzzle. An Impact Brief. University of Toronto. May. 2018. The Class of 2008. An Impact Brief. University of Toronto. May.

Robson, William B.P., Alexandre Laurin, and Rosalie Wyonch. 2018. Righting the Course: A Shadow Federal Budget for 2018. Commentary 503. Toronto: C.D. Howe Institute. February.

Tingle, Bryce, J. Ari Pandes, and Michael J. Robinson. 2014. “The IPO Market in Canada: What a Comparison with the United States Tells Us About a Global Problem." Canadian Business Law Journal. 54(3): 321-367. June.

TMX Group Ltd. Market Intelligence Group (MiG) Monthly Reports. Retrieved at: https://www.tsx. com/listings/current-market-statistics/mig-archives.

This E-Brief is a publication of the C.D. Howe Institute.

Daniel Schwanen is Vice President, Research, C.D. Howe Institute.

Jeremy Kronick is Associate Director, Research, C.D. Howe Institute.

Farah Omran is Junior Policy Analyst, C.D. Howe Institute.

This E-Brief is available at www.cdhowe.org.

Permission is granted to reprint this text if the content is not altered and proper attribution is provided.

The views expressed here are those of the authors. The C.D. Howe Institute does not take corporate positions on policy matters. 